\title{
Conservation Behavior in the Agricultural Societies of Java
}

\author{
R. Pasifikus Christa Wijaya', Faturochman ${ }^{2}$ \\ 1,2Faculty of Psychology, Universitas Gadjah Mada
}

\begin{abstract}
This research aimed to gain a deeper understanding of the conservation behavior in the context of the Java community. A deep exploration was conducted on the ecological value model, dynamics of ecological value activation, social attachment bias and collective efficacy in the development of the conservational movement in Menoreh hills. Ethno-phenomenological approach was made towards five subjects who were chosen using purposive sampling technique. The results showed several conclusions. Harmony of life was the main reason that animates the conservation practice. Peace was translated as biospheric values namely, niteni (pay attention carefully), gemati (nurture with affection) and altruistic value nguri-uri (maintaining a legacy for the next generation). Culturally, the agents who were able to revive the conservation movement had high participation in community activities (akeh srawung), trusted as the source of information and had networked with local policy figure (key figure) as the head of the village and the regent. Without the support of a key figure, collective efficacy would weaken due to the loss of access to the collective agreement and conformity of the conservation movement.
\end{abstract}

Keywords: collective efficacy; conservation behavior; memayu hayuning bawana

Since the birth of modern anthropocentrism at the time of the Renaissance, man and the universe began to be seen mechanically. Nature is reduced as resources that can be processed, used and controlled (Egbunu, 2013; Peursen, 1978; White, 1967). The golden age of anthropocentric views was marked by the birth of the industrial revolution (Domanska, 2010). Massive changes occurred in agriculture, manufacturing, mining, transportation, and technology. Along with the change in the orientation of human life, technological advances and the development of industrial business also bring side effects, ranging from pollution to climate change (Vitousek, 1994).

The industrial sector may be a major contributor to climate change globally, but

\footnotetext{
${ }^{1}$ Address for corespondence:

pasifikuschristawijaya@mail.ugm.ac.id
}

the agrarian sector is, in fact, responsible for the destruction of land and ecosystems. The green revolution program during the new order brought harm to the environment and humans (Esje and Daniel, 1998; Notohadiprawiro, 1993; Widiarta, Adiwibowo, and Widodo, 2011). Harvest was declined on a long-term, although the use of fertilizers and pesticides continued to increase. This condition indicates exhaustion of the land and damages the ecosystem of the rice fields has a negative impact on agriculture (Notohadiprawiro, 1993).

Agrarian communities on the other side are fertile banks for the growth of a vocal and reactive community to the damage of the ecosystem. Organic farming communities, for example, sprang as a response to the green revolution. The welfare of agricultural societies has always been integrated with the sustainability of 
natural ecosystems. The mindset rooted firmly in the farming community of Java gave birth to infused harmony ethics particularly in agricultural societies of Java (Suseno, 1984). This view is known as memayu hayuning bawana (Anshoriy and Sudarsono, 2008), which is the effort to protect the safety of the world, both physically and spiritually (Endraswara, 2013).

Javanese people in the Menoreh Hills also still hold this local value. Inversely proportional to the high potential land damage, the actual land damages are rarely found (Juhadi, Tjahyono, and Arifudin, 2014; Mulyaningsih, Sampurno, Zaim, Puradimaja, Bronto, and Siregar, 2006). It conjures up the assumption of the existence of local wisdom that infuses environmental sustainability (Juhadi et al., 2014). The Menoreh Hills by the time this research was written, still had good biodiversity (Herwanto, Sudarsono, and Saeful, 2013).

Unfortunately, this condition is not free from threats. The modern monoculture agriculture requires treatment (uniformity) of seeds (manufactured quality), synthetic pesticides and synthetic fertilizers in an amount much higher than the natural farming system so that it can disturb the natural balance of the ecosystem as a whole. Open hunting would destroy the diversity of wildlife that is necessary to keep the rest of the ecosystem. The practice of electrocuting fish, as well as the use of poison to hunt fish, will cause them to be infertile and kill their fingerlings.

Some members of the public are willing to spread the importance of environmental awareness through a wide channel to address this issue. This study placed an interest in uncovering traces of local agent behavior care, i.e., groups of farmers who develop local fruit tree seedlings (agroforestry), groups of farmers who maintain the natural farming systems (traditional organic system) and the driving force of the anti-poaching in the Menoreh Hills. The development of the group, imbued by memayu hayuning bawana as the value of the local ecology.

Using the conservation psychology approach, this research focused on the model of ecological value (Dunlap and Van Liere, 1978; Dunlap, Van Liere, Mertig and Jones, 2000; Schwartz, 1992; Schultz and Zelezny, 1998; Schwartz, 1977; Stern, Dietz, Abel, Guagnano, and Kalof, 1999; Van Liere and Dunlap, 1978; Stern, 2000), conservation intention (Steg and De Groot, 2010; Steg and Vlek, 2009), social identity (Stets and Burke, 2000; Turner and Tajfel, 1986) and the efficacy of conservation behavioral as dimensions of psychology that animates the presence of conservation movements (Koger and Scott, 2007).

How the form of the psychological dynamics embodied in the above dimensions becomes an important question that needs to be explicitly explained (Saunders 2003, Saunders and Myers, 2003), especially in the context of agrarian societies.

\section{Methods}

This study used qualitative methods (Moleong, 2010) with an ethnographic approach (Spradley, 1997) and phenomenology (Moustakas, 1994) from here on referred to as ethno-phenomenology. The sample consisted of five research subjects, five informants, and four participants from three communities, i.e., local-seed activists, natural farming activists and antipoaching communities. The location of the research was Kalibawang, Kulonprogo Regency. 
Table 1.

Respondent Data

\begin{tabular}{lrll}
\hline \multicolumn{1}{c}{$\begin{array}{c}\text { Conservation } \\
\text { Behavior }\end{array}$} & Subject & \multicolumn{1}{c}{ Sex, Age, Status } & \multicolumn{1}{c}{ Education } \\
\hline Anti-poaching & Ant & Male, 58 years old, married & Police academy \\
Anti-poaching & Yl & Male, 42 years old, married & Noncommissioned officer \\
Natural Farmer & Kc & Male, 28 years old, unmarried & Bachelor's Degree \\
Natural Farmer & Ad & Male, 65 years old, married & Elementary School \\
Local seed breeder & Gt & Male, 60 years old, married & Elementary School \\
\hline
\end{tabular}

The subjects were chosen through purposive sampling. The criteria for the selection and assignment were: 1) they were citizens of the community in the Menoreh Hills, 2) nature conservationists, 3) had an agricultural background, 4) came from farming families or lived in an agricultural environment. Data collection techniques used in this research were observation and interview.
The interview was conducted in-depth and informal, using open-ended questions. The process of data collection was done following the back and forth pattern (Creswell, 2007). The process of interview and observation on the subject and the subject's activities along the community ran for three months (April - June 2016). This process was done in a free-but-guided fashion using open-ended questions, flowing, interactive and informal.

Table 2.

Significant Others' Identities (The Informant)

\begin{tabular}{llll}
\hline $\begin{array}{c}\text { Significant } \\
\text { others }\end{array}$ & \multicolumn{1}{c}{$\begin{array}{c}\text { Relationship with } \\
\text { the subject }\end{array}$} & \multicolumn{1}{c}{ Gender, Age, Status } & \multicolumn{1}{c}{ Education } \\
\hline $\mathrm{Skn}$ & Mother of Kc & Female, 52 years old, Widow & Middle School \\
$\mathrm{Nh}$ & Wife of AD & Woman, 62 years old, married & Elementary School \\
$\mathrm{Bn}$ & Child of AD & Male, 29 years old, married & Diploma 3 \\
$\mathrm{Rw}$ & Wife of GT & Female, 44 years old, married & Elementary School \\
$\mathrm{Dd}$ & & Male, 24 years old, unmarried & Bachelor's Degree \\
\hline
\end{tabular}

Table 3.

Participants' Identities

\begin{tabular}{|c|c|c|c|}
\hline Participants & Gender, Age, Status & Gender, Age, Status & Education \\
\hline Kms & $\begin{array}{l}\text { Local resident, working on a repair shop } \\
\text { (one of the places at which youth meet) }\end{array}$ & $\begin{array}{l}\text { Male, } 44 \text { years old, } \\
\text { married }\end{array}$ & High School \\
\hline Ags & Friend of $\mathrm{Yl}$ and Ant & $\begin{array}{l}\text { Male, } 60 \text { years old, } \\
\text { married }\end{array}$ & High School \\
\hline NN 1 & Fisherman in the research area & & \\
\hline NN 2 & Local street food vendor & & \\
\hline
\end{tabular}




\section{Results}

There were several themes obtained in this research. The first theme was the meaning of environment: nature is a fellow in life. Nature was seen to "possess", "feel", "stress", and "lives like human", so that we can "ask plants and animals". Nature "gives blessing and gratification for farmers". This theme showed the cognitive representation of the actors of the conservation of nature, plants, and animals. Nature was seen from the perspective of life, emphasizing on the fact that nature is alive.

"Plants are living things, living as in organic, as I said before. So, there is a life process of how things are supposed to be like" AD (401-403)

Nature had been described as a valid subject to build social interaction with the humans. Nature had the same historical sense with man, on par as fellow members of the universe.

Second theme was the relation of nature and man, which consisted of sense of closeness with nature and sense of calmness and happiness. It was revealed that "feeling close to nature", "suitable", already "fits", and having "contact with plants and animals" were the reason for subject to "feel bad about treating nature arbitrarily".

"I already feel in sync with plants and animals. I cannot bear to push you (nature) by using this (chemical fertilizer), because you are alive, too. ... I became a farmer because I was already comfortable with nature, I have been very comfortable, with plants and animals." KC (67-72).

This closeness was further expressed in the arts and the "tetembangan" (folk songs), the "touch back" in their inner nature shades. On this theme, the subjects revealed their psychological closeness with nature, plants, and animals. Building closeness could be done in daily life, through the habit of having direct contacts with plants and animals, get in touch with their lives. Understanding nature could not be fully accomplished through learning from books, readings, and stories.

It was also revealed, the presence of "calmness and inner peace", especially happened when they "hear the voice of nature, crickets, birds, and wind", "inhaling a breath of fresh air", "smelling the aroma of herbs and fruits" and "enjoying the diverse atmosphere". A feeling of "joy in seeing bird feeding" was aroused.

"I wish, because during my childhood there were plenty of birds, I wish it could stay that way until my olden days. So, it's as if, when I hear birds, these sounds are heart-warming. That's what keeps me going." ANT (245-248)

Getting in touch with nature had a therapeutic function, to "reduce stress" and "strengthen during tough times". This theme revealed the emotional response that arises when interacting with animals, plants and nature. Being close to nature provided a sense of peace, security, serenity and joy.

"Why did older day people rarely suffer from stroke? People were never hasty; their minds were peaceful and not full of greed. Walking on the fields whilst listening to birds chirping... If there is no entertainment after you work, you would become stressed"

Third theme was the role of man on improving nature's sustainability: a) become the keeper of life, b) guard the legacy for future generations, and c) 
become independent (from chemical and industrial product) alongside sustainable nature. Human beings had the duty to "not usurp the right to live, whether plants or animals" and "not arbitrarily kill for personal pleasure".

"And once again, man cannot live on his own. Living together with our fellow human beings, animals, plants, you should not usurp the rights of other living things for your fulfilment, you want to get rich, prosperous, you then seize the right to live, although not directly."

Hopefully, anyone dealing with nature used "compassion", "heart", and wants to "pay careful attention". In general, the value that appeared was derived from "memayu hayuning bawana". When negative human behavior disappears, it is believed that the beautiful and ideal nature will restore itself the way it should be. This view is the characteristic of Javanese ecological values. Furthermore, this theme also revealed about a legacy for future generations. Conservation behavior was shown due to the consideration of the welfare of future generations. The subjects considered the sustainability of nature that they were currently striving for would be "beneficial for their descendants".

"I am doing this for my descendants. Five years into the future there will be no more dependence of seedlings, even developing 5000 seeds is a task that can be accomplished. That is why I made these clones, with the knowledge of the BPSB". GT (424-428)

This value was then "taught" to younger generations (generativity). These themes illustrated the altruistic values of subjects in relation to nature.

"I (invite) these youth, I have them watch, and if anyone is shooting I am to be notified by SMS. I tell them, if you don't have the courage to confront, or you have told them but they refuse to stop, tell me." YL (251254)

This value was defined as the belief in which man must choose a behavior that is beneficial to others, or in other words, putting the interests of others as the basis for conservation decisions. Another role of man against nature's sustainability was to be independent alongside sustainable nature. This theme appeared specifically in the context of eco-friendly agriculture. Independence was defined as a reduced reliance on external inputs. Plants were no longer dependent on manufactured fertilizers and pesticides. Humans could also reduce dependence on market consumption.

“...only using those compost and liquid fertilizer, even nowadays I usually only use "green" for plants. Only using herbaceous and foliage, spread around the plant and flushed with liquid fertilizer. It has shown similar results with NPK. The ones above are not given NPK, those who don't know would think they have been given NPK, when "pupus", when new sprouts are rising they only reach $20 \mathrm{~cm}$, with the leaves. That's at maximum fertility ... restoring fertility takes 10 years. Because the ground has already been sick for a long time too. If it were neutral, it would not take long".

Conventional farming required no small amount of capital, due to dependency on synthetic fertilizer, seed, and farm implements. Those who were reluctant to constantly rely on outside resources, turned to a more environmentally friendly agriculture. Restoring the farmland as a self-contained ecosystem, became the main method. 


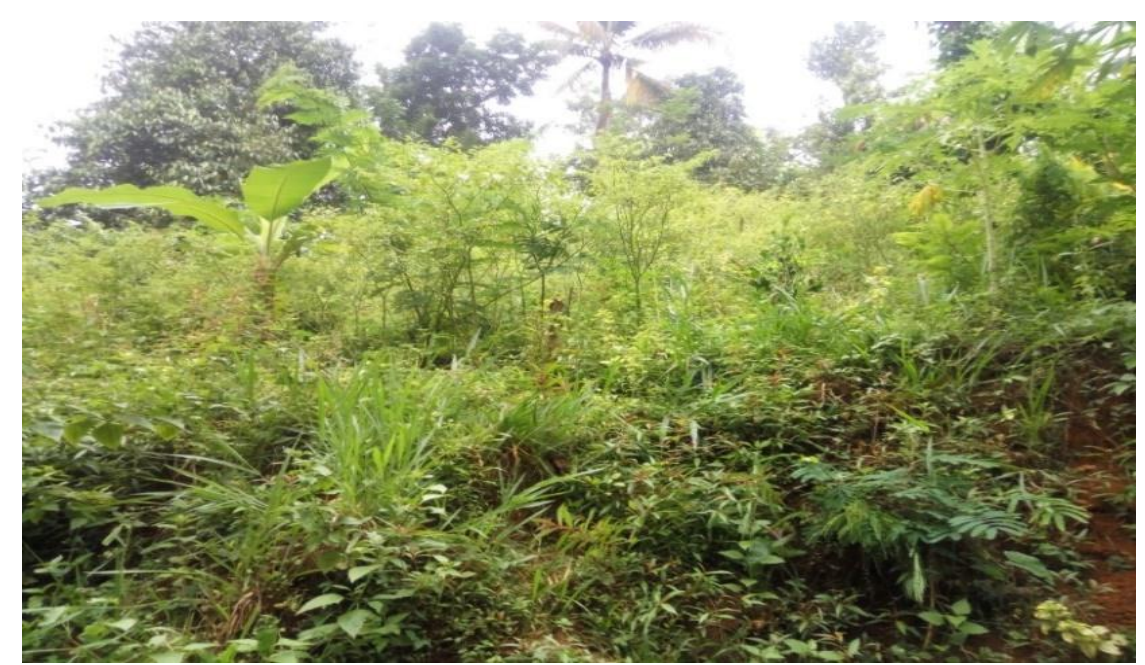

Picture 1. Farming chillies naturally using no-till farming (TOT), without synthetic pesticides/fertilizers on Menoreh Hills

The fourth theme obtained in this research was that threats to the sustainability of nature are mostly been done by man. Neglecting the diversity of surrounding life was considered as a common cause of damage to the diversity of the flora and fauna. This theme reflected the experience of feeling the negative impact of human behavior on the environment. It was revealed that once, "land became corrupted and hard", "plants dry out and die" and "the diversity of local varieties goes extinct".

"I used to like using chemical fertilizers. After the training from Salatiga, I was told that if you don't use chemical fertilizers, the results wouldn't be as good. It turns out the cloves I had should be watered regularly, while my neighbor's didn't have to. Because of that manufactured fertilizer. If not given manufactured fertilizer, they're safe (during the dry season)" GT (299-305)

"(The Kacer bird) used to be plentiful here. The reason for their extinction is poaching." ANT (28)

"What are squirrels like in the countryside? How are these not found here?" YL (22)

Responding to the negative effects, they exhibited affective response of "irritation" against perpetrators for destroying and empathizing with nature by "regretting" that "arbitrary" behavior. Whoever had damaged the environment felt "regret" and "worry when seeing others do it." There were also concerns that "pesticides interfere with health". Another effort to conserve nature is a courage to act. The theme reflected the decisionmaking process in response to environmental damage. The courage to act, became the turning point of the journey of the subject. Intention to restore a beautiful nature is manifested in private decisions.

"At first I was on my own. At that time there was a neighbour who used to catch birds with traps made from glue/sap, I gradually told them" YL (74-75)

Adequate information was needed about the environmental problems that were being encountered, knowledge about ways to improve environmental conditions and subjects' capabilities (efficacy) to execute. 
"Information, knowledge and network, these are what is expected of a driving force" (KC)

After sufficient network was built and joint actions were formed, those who have "experience" were referred to as examples, role model, a place to ask when encountering problems. A willing to make sacrifices in the struggle is one effort of nature conservations as well. Challenges turned out to come from various lines. No doubt, the crashing down and rising up again became the most emotional moments of sharing their story. For the subjects, "the hope of the future" and "commitment" became the stepping stones to keep going.

"Secondly, it certainly requires bold sacrifice, because put it this way, my enthusiasm here, if I didn't have it the birds would all be gone, the fish would also go extinct. That is why I order these one by one until there are 30 (prohibition signs) which are installed, I keep ordering these again (using own money)." ANT (17-21)

Faced with a challenge, the subjects chose to be "gelem rekasa" (willing to live in distress/hard work), seeing conservation decisions as "a calling"; they were ready to make "personal sacrifices" and "finance from their own pockets."

"If not for the calling, I would have stopped long ago." KC (203-207)

The last theme obtained in this research is institutionalization. Community or group became a place to embrace personal closeness to construct conservation discourse. Some of the personal paths used to spread the conservation discourse are "close relation to village youth", "friend who happens to be serving in the village", "family", "neighbours" and "friend of the family members".
"If my own neighbourhood left unmaintained, then that isn't organic. Starting from my neighbourhood though only a few people, from this scope, would be good if it can be expanded a little to the outside community."

The sustainability of nature was difficult to achieve individually. Working with the community is always a popular choice, and needs to continue to be pushed. Two major tendencies noticeable in persuading, namely "through individuals who have had personal closeness" and "through individuals who have the same interests". Existing personal proximity facilitated the efforts of persuasion. Institutionalization can also be a means to unite steps in groups. The theme reflected the significance of the group for the subject. Through the group, the conservation behavior gets a "normative foundation", "binds" members of the group through the "vision and mission", "compromise", "mutual agreement" and the "work program". Conformity in groups was built this way.

"Regarding the farming patterns (natural), there are those who follow and those who don't. Lately I submitted a proposal to the "sendang mekar" so that this would become a regular working program (natural method), creating small groups" (249251)

Further, groups provided the basic social identity to distinguish "we (who fought to preserve)" and "they (who neglect and damage the environment)". The social comparison sprang from selfesteem, "we are better than them". Both constructs, the bonds of conformity and self-esteem, became the fuel that was needed to maintain the conservation behavior. 
Furthermore, institution was also expected to provide supports for those who care about the environment. The decision to maintain environmental sustainability had a high value, inviting admiration and support because it was regarded as a behavior that "can always be morally justified", thus gaining "recognition" and "praise", increasing confidence. Support in the form of knowledge and training also helped increasing the success of the effort. Material support came as a means of assistance from institutions. The strongest mental support came from the family. Their support was what causing these actors to continue to survive.

\section{Discussion}

Javanese sees the human being as microcosmos that is not detached from the universe (macrocosmos), mutually absorbing in life (Jatman, 1997; Suseno, 1984). At this point, the biospheres' value is no longer opposing the egoistic value, as they are indeed mutually absorbing. The goal to be achieved is the safety of the entire universe. This condition is characterized by the presence of peace. In the mind of an agrarian Javanese, the union of this universe of value is translated through memayu hayuning bawana, derived into practice as gemati, niteni and nguri-uri.

Niteni is the sensitivity of rasa (awareness) to get the proper layout for humans in the order of the universe. The art of managing awareness is done by distancing ourselves from distractions (goda rencana), putting ourselves in a safe situation (slamet), and increasing expectations to achieve success (dadi). Niteni as a method, is performed by determining the signs that precede an important event/condition. The result of niteni is summed up in titenan. The most common form of titenan is: "If ... (markers), then ... (important events/circumstances)". Preferably, in the process of drawing the conclusion, logical explanations which based the conclusions need not be built in depth. The level of truth of a conclusion of titenan is not determined by logical explanations, but rather determined by repetitive predictive accuracy (othak-athikgathuk). Titenan conclusions will be considered correct if the observable signs can exactly predict certain events or circumstances.

"How did people in the past come up with such notion? This is the wilting season of temu ngleyang, in May, shown by the calendar as pranata

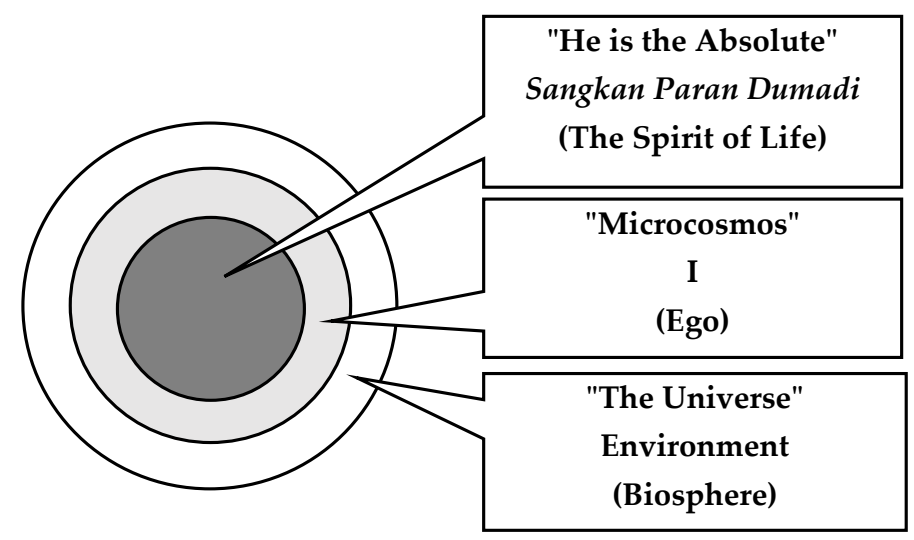

Figure 1. The nature of human beings. Adapted from Psikologi Jawa by Jatman, 1997. 
mangsa month eleven. Observe (titeni) and you'll see that during the season when leaves wilt, humans are also more prone to sickness, added by the irregular heat and rain" AD (16-25)

Based on this explanation, titenan has two functions. First, to provide an explanation regarding the rhythm of nature at this time. This explanation brings nature from being originally alien and dark, to a reality that is easier to understand (Suseno, 1984). Anxiety facing unexpected situations will be suppressed, as he has been able to recognize his life spaces and interpret life at the current moment. The second function is to give a predictive overview about the condition that would be faced, along with the threats that follow. Niteni becomes the framework of "the cognitive method in dealing with a situation of uncertainty (Leach, 2004)". Using titenan as a predictive construct also allows one to organize the necessary resources. Planning and organizing is done along with other members of society (gotong royong, in group). Anxiety can be suppressed because someone feels they have been preparing appropriately ("ngupaya daya") to survive the disruption ("adoh seka goda rencana").
Nguri-uri teaches humans to dispose of negative behavior that could interfere with the occurrence of "ideal conditions". Nature is created in perfect conditions, good as it is. The ideal natural order, in this point of view, is not an "objective natural order" but "ideal order" as it was created. Rain falls, water flows, fish swim in the river, birds chirp on the trees. Life is suspended in that condition, farm in the rainy season, fish in the river, and rest while listening to "sounds of nature" (nglaras). Habits that are believed to "not destroy" ideal order are sought to be maintained. It is understandable then, why some of the subjects maintain natural farming patterns derived from the previous generations.

Through the principle of nguri-uri, the value of memayu hayuning bawana is taught to the next generation. First, the process of modelling, the previous generation gives an overview of how the value memayu hayuning bawana is performed in everyday life (Bandura, 1977). Second, the experiential-reflective process, learning is done in natural settings, through direct experience, allowing implementation of a reflective process on that experience (Moon, 2004). The cycle of internalizing the "Memayu Hayuning Bawana" value can be broken down as attention-replication-expansion

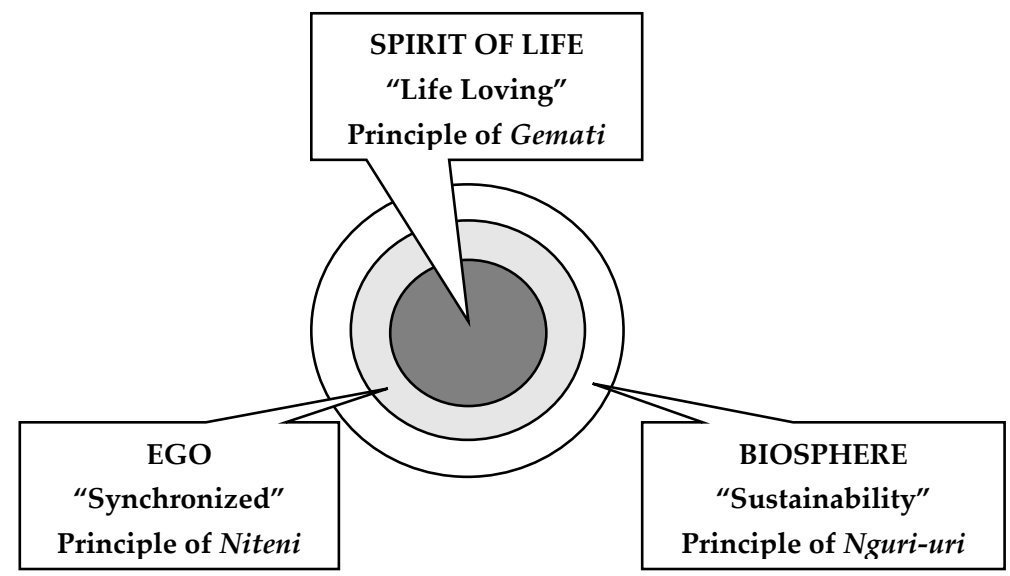

Figure 2. "Memayu Hayuning Bawana" as the model of the Javanese environmentalism 
At the "attention" (niteni) stage, the older generation invites younger generations to observe conditions and practice them in the field directly. At the niru/replication stage, conservational behavior is replicated in a form that is more or less the same with that exemplified before. The younger generation could directly mimic within the actual settings.

"That since I was a child, I was born into a community of farmers. Because in the family of humble farmers, parents inevitably have to teach farming, to be close to nature. Love the plants, love the animals. "

Nambahi/expansion phase started from reflection on activities/experiences that had been passed together through the chitchat between different generations. The behavior evaluation results were then compared with the experiences and conditions of the others.

"Urea is actually damaging, just stimulants alone. I used to join in on that as well (using urea). My soil was damaged because of the mixture of urea and chicken manure. My plants all dried up. In Plengan, there was someone named Mr WS, who used to be famous for his vast clove field. His children always said that they fertilized using urea, and now they are complaining to me, "ah I'm not inheriting any clove trees (from the parents), I need to plant again." Many of the clove trees died, due to the urea content on the soil."

This stage was used to confirm the results of the reflection. Such conclusions then could be drawn personally, based on reflection and comparison with the experience of others. At this point, the definition of experience was no longer "imitation", thus became reflection-basedvalues.

"Humans cannot be separated from nature. Humans live only from nature, so maintain it. Basically that. My faith, I live in nature. No matter how rich I become, how prosperous I become, how wealthy I become, whatever I eat comes from this earth. So, maintain nature so that you can keep eating, keep living."

Self-efficacy to behave in a conservational manner tends to be high. Javanese culture, through memayu hayuning bawana, provides clues about the conservation point of view. The conservation behavior is seen as an attempt to keep the inner peace, which is taught from generation to generation.

The modelling process to teach conservational behavior becomes a commonly found approach, because conservation behavior is not separated from everyday life. Together with children making organic fertilizer from animal droppings, paying attention to the state of nature and finding peace in a beautiful atmosphere, becomes an example of how conservation behavior is taught. A person's success in learning conservational values and behavior from Javanese culture models, improved self-efficacy in conducting conservation behavior. In addition, the inner harmony is felt when managing to maintain environmental sustainability, reduces negative emotions that reduce the self-efficacy. Hearing back the sound of birds in the village after many years of successfully banning poaching, brought a sense of peace and improves self-efficacy to continue to do so.

Unfortunately, high self-efficacy might not necessarily be followed by high collective efficacy. Reflecting on the 
conservation group experience in Menoreh, collective efficacy to maintain the environment tend to be weak. The success or failure to encourage the development of anticipatory conservation behavior depended on factors outside the group.

"Well I start by inviting those who want to join. My son also told me, Father, you want to invite people (as a lone initiator), dragging along ten people, are you strong enough? Well sometimes I think that society can be... tiring. (My son tells me) Put it this way, if you were to cry, they wouldn't know that you are crying. Let them be, just invite those who want to join in, despite coming from a different village."

Javanese culture tends to be communalist, holding dearly the principle of harmony, preventing all friction due to differences of opinion and interests (Suseno, 1984). The group often felt powerless when faced with the refusal of other community members. Decisions that could bind the behavior the whole community can only be formed through communal deliberation in the village. They felt they have no control over the results of "fighting for environmental sustainability", everything still depended on the community. The success was attributed to village community's agreement.

"Synergizing in all aspects is not possible, but synergizing in the things that can work together in a match is what I was looking for. In the end, whoever can synergize, can fit, those are the ones that I invite. Thus between one mover with another mover, in terms of like-mindedness, that is what continues to be fostered."
Although the value of the memayu hayuning bawana was still absorbed widely in the natural life of the Menoreh community, community members did not always have the same opinion about conservational behavior. Differences of opinion between members of the community arose from the difference in degree of environmental support. Bad effects of environmental destruction behavior do not happen instantaneously. It takes time before environmental damage is observable.

The chronic shooting of birds and wild animals will only show systemic effects after the damage becomes irreparable. The application of pesticides, herbicides and chemical fertilizers in the short term will increase plant productivity, but will reduce fertility in the long term. The Indonesian agriculture sector itself has only realized the shortcomings of green revolution after 20 years (Notohadiprawiro, 1993). Currently, most of the farmland in Indonesia can no longer thrive without the application of chemical substances, due to its high dependency.

When conservational behavior is not considered worthy of being labelled "important" for the sake of the whole community, then it is unlikely that such issues are raised in formal community discussions. This condition develops as a pessimistic view (mikir masyarakat nggawe rekasa) when discussing the position of conservation in the community.

High self-efficacy allows conservation groups to be easily formed, however, collective efficacy tends to be weak and has external locus, limiting the performance of the conservation groups that are formed. Groups easily stall when faced with differences of opinion within the community. 


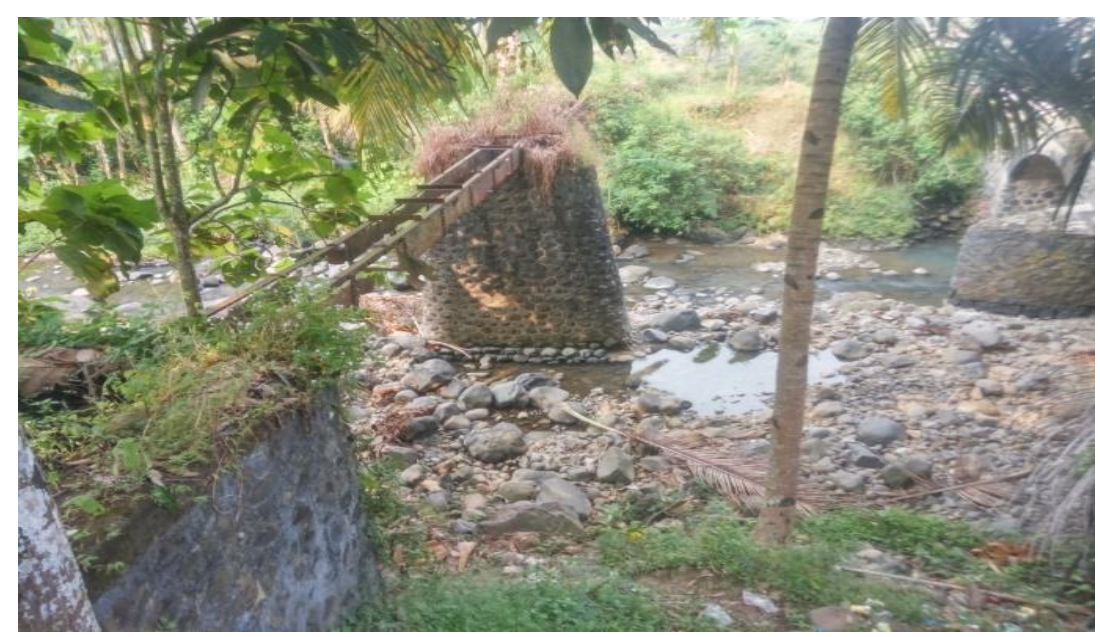

Picture 2. The location of the initial installation of the poaching prohibition sign, which was destroyed by an "unidentified person"

Cognitive social theory explained the factors that affect the collective efficacy (Bandura, 1998). The high dependence of a group in the presence of outsiders reduces the level of collective efficacy. This condition is referred to as collective powerlessness. Faced with a high reliance on external factors, the conservation group develop locality strategies.

The plan to achieve something that involved the wider community was stopped, and they turned the surrounding environment that was capable of being influenced. Social cognitive theory explains that a similar strategy is done to regain control over the accomplishments of the group (Bandura, 1998). Although the issue raised included the benefit of the whole community (ayem tentrem), their movement was limited to a narrow social circle.

The above process was often referred to as the "think global, act local" (Bandura, 1998, 2000). Particularly applied to ecological issues, this jargon proves to be able to maintain the efficacy of the group in order not to completely collapse. Thus, conservational efforts could continue to be maintained within the scope of the groups, families, neighbors or close friends.
"I stick with how the community wants it to be. I embrace the youth organization, to make those banners together."

The role of the parties who were able to bring the issue of conservation in harmony with the interests of the wider community, such as the role of village government, becomes a key role. Through them, the environmental issue is transformed into a two-sided issue, such as safeguarding the environment while maintaining security of the village from outsiders (in the context of anti-poaching) or safeguarding the environment while enhancing income of the farmers (in the context of agriculture).

"Communicate with the individuals (who work in the sub-district office), enter through the individuals. From this starting point, it shall be spread. During village coordination meetings, these are to be put forward. In order to better spread it. "

After the two-sided conservation issue emerged, then he will be able to embrace broader community members so that it was appropriate to put forward in village discussions. 


\section{Conclusion}

Memayu Hayuning Bawana is a local biospheric value that still permeates today. The main principles of memayu hayuning bawana are gemati (nourish life with affection), niteni (manage feelings to place oneself properly in the order of the universe) and nguri-uri (willingness to maintain nature preservation in good condition). These three are performed with hopes of getting the peace in life. Internalization of values involves a process of modelling and reflection on direct experience.

Self-efficacy to perform conservation behavior tend to be high, but the collective efficacy appeared weak and had an external locus. Consequently, the conservation group can be easily formed, but their performance was dependent on external factors. Strategies to improve the collective efficacy consisted of two main parts. First, the "think global, act local" by limiting the scope where conservation behavior was implemented. Second, approaching the institution and capturing every support available. Government policy support, government agencies, and community leaders became the pathway for conservation groups to improve collective efficacy. Together with government institutions, building a community agreement would be easier to be done.

\section{Recommendations}

Considering the existence of strong social closeness nuances from the development of anti-poaching discourses, efforts to bring each of the group members closer personally becomes the key of success and sustainability of an action. Expanding the network of movements can be done by approaching the "elders," village chief, head of RT and RW from neighbouring areas and establishing communication with individuals from surrounding villages who have similar actions, though it is done individually.

Developing local seeds and natural farming methods without soil processing admittedly require hard work and negotiations when dealing with the agricultural community. Discussions with the two themes above need to continue to build conservational discourse. When dealing with the difference of ideas or disapproval, referring the conservation discourse back to the visions and missions of the farming group needs to be done to improve conformity.

There is no denying, the role of institutions is vital in the development of the conservational movement. Institutional policies even become the norm carried by the conservation drivers in doing persuasions within the society. It is expected that institutions, local and village governments are more considerate and willing to issue a conservation regulation that is appropriate to the context of local environmental problems that are being encountered, such as the issuance of a permit for possession of airguns. Law enforcement and the law, also cannot be abandoned.

\section{References}

Anshoriy, N., \& Sudarsono. (2008). Kearifan lingkungan: Dalam perspektif budaya Jawa. Jakarta: Yayasan Obor Indonesia.

Bandura, A. (2000). Exercise of human agency through collective efficacy. American Pschological Society, 9(3), 7578. doi: $\underline{10.1111 / 1467-8721.00064}$

Bandura, A. (1977). Social learning theory. New Jersey: Prentice-Hall 
Bandura, A. (1998). Personal and collective efficacy in human adaptation and change. Advances in Psychological Science, 1, 51-71.

Creswell, J. W. (2007). Qualitative inquiry and research design: Choosing among five approaches (2nd edition). Thousand Oaks, CA: Sage

Domanska, E. (2010). Beyond anthropocentrism in historical studies. Historein, 10, 118-130.

Dunlap, R. E. \& Van Liere, K. (1978). The new environmental paradigm. Journal of Environmental Education, 9, 10-19.

Dunlap, R. E., Van Liere, K., Mertig, A. G., \& Jones, R. E. (2000). Measuring endorsement of the new ecological paradigm: A revised NEP scale. Journal of Social issue, 56(3), 425-442.

Egbunu, F. E. (2013). Personhood (one) in Igala worldview: A philosophical appraisal. Cross-Cultural Communication, 9(3), 30-38.

Endraswara, S. (2013). Memayu hayuning bawana. Yogyakarta: Narasi.

Esje, G. \& Daniel. (1998, Juli-Agustus). Menggugat revolusi hijau orde baru. Tabloid Wacana, 12.

Herwanto, J. E., Sudarsono, A., \& Saeful, B. (2013). Pemanfaatan sistem informasi geografis untuk evaluasi kemampuan lahan dan arahan penggunaan lahan di kecamatan Samigaluh Kabupaten Kulon Progo. Geomedia, 11, 42-51. doi: $\underline{10.21831 / \mathrm{gm} . v 11 i 1.3567}$

Jatman, D. (1997). Psikologi Jawa. Yogyakarta: Yayasan Kayoman.

Juhadi, Tjahyono H., \& Arifudin R. (2014). Analisis spasial tipologi kerusakan lahan berbasis sistem informasi geografis. Jurnal Tata Loka, 16(4), 209219. doi: 10.14710/tataloka.16.4.209-219

Koger, S. M, \& Scott B. A. (2007).
Psychology and environmental sustainability: A call for integration. Teaching of Psychology, 34, 10-18.

Leach, J. (2004). Why people 'freeze' in an emergency: Temporal and cognitive constraints on survival responses. Aviatin, Space, and Environmental Medicine, 75(6), 539-542.

Moleong, L. J. (2010). Metodologi penelitian kualitatif. Bandung: Remaja Rosda Karya.

Moon, J. A. (2004). A handbook of reflective and experiental learning: Theory and practice. New York, NY: Routeledge Falmer.

Moustakas, C. (1994). Phenomenological research methods. California: Sage Pub.

Mulyaningsih, S., Sampurno, Zaim, Y., Puradimaja, D.J., Bronto, S., \& Siregar, D.A. (2006). Perkembangan geologi pada kuarter awal sampai masa sejarah di dataran Yogyakarta. Jurnal Geologi Indonesia, 1(2), 103-113.

Notohadiprawiro, T. (1993). Tanah dan lingkungan. Jakarta: Depdikbud.

Peursen, C. A. (1978). Strategi kebudayaan (D. Hartoko, Trans). Yogyakarta: Yayasan Kanisius.

Saunders, C. D. (2003). The emerging field of conservation psychology. Human Ecology Review, 10, 137-149.

Saunders, C. D., \& Myers, O. E. (2003). Exploring the potential of conservation psychology. Human Ecology Review, 10(2), 3-8.

Schultz, P. W., \& Zelezny, L. C. (1998). Values and conservational behavior. Afive-country survey. Journal of CrossCultural Psychology, 29, 540-558.

Schulz, R. (1978). The psychology of death, dying, and bereavement. Reading, MA: Addison-Wesley 
Schwartz, S. H. (1977). Normative influence on altruism. Advances in Experimental Social Psychology, 10, 221279.

Schwartz, S. H. (1992). Universals in the content and structure of values: Theoretical advances and empirical tests in 20 countries. Advances in Experimental Social Psychology, 25, 1-65. doi: 10.1016/S0065-2601(08)60281-6

Spradley, J. P. (1997). Metode etnografi. Yogyakarta: Tiara Wacana Yogya.

Steg, L., \& De Groot, J. (2010). Explaining prosocial intentions: Testing causal relationships in the norm activation model. British Journal of Social Psychology, 49, 725-743. doi: $\underline{10.1348 / 014466609 \times 477745}$

Steg, L., \& Vlek, C. (2009). Encouraging conservational behavior: An integrative review and research agenda. Journal of Environmental Psychology, 29, 309-317. doi: 10.1016/j.jenvp.2008. $\underline{10.004}$

Stern, P. (2000). New environmental theories: Toward a coherent theory of environmentally significant behavior. Journal of Social Issues, 56(3), 407-424. doi: $10.1111 / 0022-4537.00175$

Stern, P. C., Dietz, T., Abel, T., Guagnano, G. A., \& Kalof. (1999). A value belief norm theory of support for social movement: The case of environmentalism. Human Ecology Review, 6(2), 81-97.

Stets, J. E., \& Burke, P. J. (2000). Identity theory and social identity theory. Social Psychology Quarterly, 63(3), 224237.

Suseno, F. M. (1984). Etika Jawa: Sebuah analisa falsafi tentang kebijaksanaan hidup Jawa. Jakarta: Gramedia.

Turner, J. C., \& Tajfel, H. (1986). The social identity theory of intergroup behavior. Psychology of Intergroup Relations, 7-24.

Van Liere, K. D., \& Dunlap, R. E. (1978). Moral norms and environmental behavior: An application of Schwartz's norm-activation model to yard burning. Journal of Applied Social Psychology, 8, 174-188. doi: 10.1111/j.1559-1816.1978.tb00775.x

Vitousek, P. M. (1994). Beyond global warming: Ecology and global change. Ecology, 75(7), 1861-1876.

White, L. (1967). The historical roots of our ecologic crisis. Science, 155, 1203-1207. doi: $10.1126 /$ science.155.3767.1203

Widiarta A., Adiwibowo S., \& Widodo W. (2011). Analisis berkelanjutan praktik pertanian organik di kalangan petani. Sodality: Jurnal Sosiologi Pedesaan, 5(1), 71-89. 